\title{
FAIRY STORY INTEGRATION FOR MEANINGFUL CLASSROOM
}

\author{
Muhammad Nur Wangid ${ }^{1}$,Ali Mustadi, and Agnestasia Ramadhani Putri \\ Post Graduate Program,Yogyakarta State University \\ 'e-mail: m_nurwangid@uny.ac.id
}

\begin{abstract}
The National Indonesian Ministry of Education expresses the importance of educating friendliness by stating it in a Master Plan of National Character Development for 2010-2015. However the success of character education needs a meaningful classroom situation. Unfortunately, teaching materials to create meaningful classroom situation that enhances friendliness character is still rare. Sainsmatika fairytale books are science and mathematic's teaching material which was developed with the wisdom of fairytale, which is attractive to integrate friendliness value. The study aimed to investigate the effectiveness of sainsmatika fairytale books as a means of integrating friendliness into teaching materialsfor fourth-grade students in Indonesia. A pretest-posttest control-group experimental design was used in this study to investigate the product effectiveness. This study involved 80 fourthgrade students at one of the districts in Indonesia. The experimental group was taught using sainsmatika fairytale books containing one of the character values in character education, i.e., friendliness. The quantitative data were collected through observation on student activity. The data were then analyzed using statistical methods to calculate the values and determine the frequency as well as the mean of pretest and posttest scores in both control and experimental groups. Through one way ANOVA statistical analysis, it was found that the use of sainsmatika fairytale books is significantly effective to enhance the student friendliness.
\end{abstract}

Kata Kunci: fairy stories, sainsmatika, friendliness character

\section{INTEGRASI CERITA DONGENG UNTUK PEMBELAJARAN BERMAKNA}

\begin{abstract}
Abstrak: Kementerian Pendidikan Nasional Indonesia mengekspresikan pentingnya mengajarkan karakter bersahabat dengan memasukkannya ke dalam Master Plan Pengembangan Karakter Nasional 2010-2015. Keberhasilan pendidikan karakter mebutuhkan situasi pembelajaran yang bermakna. Bahan ajar untuk menciptakan situasi pembelajaran bermakna yang dapat meningkatkan karakter bersahabat masih kurang. Buku dongeng sainsmatika adalah bahan ajar sains dan matematika yang dikembangkan dengan pendekatan kearifan dongeng yang menarik untuk diintegrasikan dengan nilai karakter bersahabat. Penelitian ini bertujuan untuk untuk mengetahui keefektifan buku dongeng sainsmatika sebagai bahan ajar terhadap karakter bersahabat siswa. Penelitian menggunakan pendekatan experimental pretest-posttest control-group design. Sebanyak 80 siswa kelas 4 sekolah dasar di salah satu provinsi di Indonesia dilibatkan dalam penelitian ini. Setiap kelas eksperimen belajar menggunakan buku dongeng sainsmatika. Data dikumpulkan dengan menggunakan teknik observasi dan dianalisis dengan teknik statistik anova untuk menghitung frekuensi dan rata-rata hitung pretes dan postes baik kelas eksperimen maupun kelas kontrol. Hasil penelitian menunjukkan bahwa penggunaan buku dongeng sainsmatika mampu meningkatkan karakter bersahabat siswasecara signifikan.
\end{abstract}

Keywords: dongeng, sainsmatika, karakter bersahabat

\section{INTRODUCTION}

Every child is a part of society. In the next decade, children will grow up and become change makers of the world. As a part of society, children needs to be a friendly individual who have friendliness value such as showing genuine respect, caring for others, and communicating well. Friendliness is essential skill which important for student in all level of education. Children who have friends are more confident and accomplish better performance than those without friend. Unfortunately, most children had difficulty to make friendship with other. When children have difficulty in making friendship, it 
encourage negative self-concept, feeling lonely and rejected by others. The three-year study in Florida show which involved 130 girls and 101 boys in the third and fifth grades, found that children who reject in circle is children with poorer socisl skills or perceived as overly aggressive. Social deficit also causes difficulties in children development (Bennett, et.al., 2009). In other hand, child's pals can protect children from sadness, anxiety and even depression (Borba.2015).

Indonesia Government expressed the importance of educating friendliness, by stating a Master Plan of National Character Development for 2010-2015. This masterplan aim to develop Indonesia Golden Generation who aware to human value and social responsibility, belonging to friendliness. As consequences, character education should implemented in all grade of Indonesian School. However, there is no way that a child can possess these value in an instant. To have well-developed social responsible, a child is indeed required to get actively involved in the real situations of social interaction. Going along with the above-mentioned notions, Piaget (1932), Kohlberg (1969) and domain theories affirm that the development in the moral domain is encouraged through direct interaction and children's real experiences in social relations, as well as the consequences of every action when they build relationships with others (Nucci, 2014). Therefore, teacher need to integrating character education with learning proccess.

Almost Indonesian school has implementing character education in integrated way with learning proccess in classroom, but not all character value can instructed clearly. Friendliness is a character value described as in the positive attitude toward others, eagerness to communicate, and ability to adapt easily to new environments. These interpersonal features are parts of basic social skills. However, friendliness has yet to be the concern of schools, particularly in elementary schools in some regency of Indonesia.

\section{Friendliness Indicators}

"Friendliness is the best cure for loneliness" (Chandler, 2012). Being friendliness is effort to make another people feel welcomed. Friendliness defined by Fathurrohman, et al (2013) as the behavioral virtue of being kindly communicative and eager to make friends and cooperate with other people. The fact of children with ability to build friendliness have a skill to take pleasure in all activity, make relationship, and play with another children easily (Grose, 2008). Friendliness expresses in actions that demonstrate a sense of love to talk, hangout, and working with others (Indonesia Ministry of Education, 2010). When children enjoy conversing, this indicates that they feel comfortable with their environment and possess positive self-confidence. Within the scope of learning environment, this attitude is reflected in the bright enthusiasm of the young learners to express their opinions, deliver their ideas, accept criticism and answer questions without fear. When they enjoy making friends and cooperating with other people, this means that they have the conception about friendliness.

One with a friendly personality is perceived to be an individual with great flexibility in establishing communications not only with his contemporaries, but also with other people of different ages. Another trait shown by a friendly individual is his capability of solving problems in teamwork. He does not close himself off, feels comfortable when interacting with other people,expresses his opinions clearly, respects other people's opinions, and accepts criticism with an open heart.

Theoretically, friendliness is similar to the concepts of 'social and emotional skills' proposed by Davidson, et al (2014) in 'Eight Character Strengths'. One with well-developed social and emotional skills is viewed as a human being who has healthy confidence and a positive attitude, has good manners, shows empathy and cares about others, and possesses the abilities to communicate effectively, work together with othersand cultivate his emotions. Suyadi (2013) explain friendliness as open-minded attitude to another people through polite communication therefore created good cooperation. The indicator of friendliness have proposed 7 (seven) act such as, "initiate communication", "support other", "glad to share", "open to discuss", "appreciate", "respect", and "cooperate" (Sulhan, 2011).

As mentioned above, friendliness is generally demonstrated through a cooperative and respectful attitude as well as positive thoughts toward others. According to theory which explained, the indicator of friendliness 
are sociable, glad to share, respect to other, reciprocity, and open-minded.

\section{Friendliness Traits}

Friendship require responsible act, like give and take. Australian Primary Schools Mental Health Initiative (2013) propose that children in 4 (fourth) grades comprehend the concept of friend as someone who trusts you and is trustworthy. At this age, children can express some friendship skills such as sharing with confidences, making negotiation, and respecting one another. When children success at making friendship, they have more opportunity to learn and practice many social skills (Joseph, et.al., 2010). Trial and error proccess for making friendship are several discrete behaviors that children do during playing activity that seem related to having friends (Tremblay, et.al, 1981; Joseph, et.al., 2010). Friendly act is typically expressed in mild act such as giving a greeting, waving to other, shaking hands, or doing a small favor (Hall \& Domhoff, 1967).

A friendly interaction is defined as some following types of behavior such as (1) feeling friendly without outward expression; (2) friendly in action; (3) giving or loaning something; and (4) helpful act (Hall \& Domhoff, 1967). This friendly interaction has similar defining with friendship skills which following some types of behavior such as (1) give suggestions; (2) share something (material/ non material); (3) reciprocity; (4) gives compliments; (5) understand how and when to give an apology; and (6) begins to emphatize (Joseph, et.al., 2010). Fathurrohman, et al (2013, p.111) explains that the traits of student with friendliness are: 1) the students are willing to take part in teamwork in the classroom; 2) the students want to converse with their classmates; 3) the students enjoy spending time with their classmates during recess; 4) the students enjoy interacting with other friends at school; and 5) the students confidently talk to the teachers, principal, and other school staffs.

\section{Developing Sainsmatika Fairytale Books to Enhance Friendliness}

Only through personal experiences, child can learn how to interact with other people and find the value his social life. From the perspectives of cognitive-social development theories, social interaction is very important for children because it will help develop their conceptions of social and moral rules (Smetana, 2006; Turiel, 1998). Character education should be reinforced everywhere: on the playing fields, in classroom corridors, interaction between teacher and students and even learning procces. Both science (read. sains in bahasa) and mathematics are subject which using book as teaching material. Teaching material is a systematically arranged component that presents some of the competencies that will be learned by students (Dick \& Carey, 1996: 120). Based on this opinion, the teaching materials are arranged to facilitate students learning easily. In Indonesian School, science and mathematics book not only contain both subject information, but also character education content. Unfortunately, friendliness value is not fulfilled clearly.

The ideal book for lesson character education is not about show the value on words, but also bringing up the enterprise and students awareness about social in interesting way. Every textbook that offered to children should correspond to children's cognitive and linguistic abilities to less frustrations and lack of interest in studies (Gabitov \& Ilyasova, 2016; Solnyshkina, et.al., 2017). According to it, book which easy to read and understood for children is more attractive.

Saxby (1991, p.10) states that "a good book will make the reader hear, feel, and see."According to it, a good book will make children as the reader able to hear, feel, and see another perspective. A fairy tale as a part of children's literature can be the place into which the values of character education are integrated. Furthermore, Lepin (2012, p.5) explains fairy tales do not only bring "the atmosphere of mystery, thrill and wonder which makes fairy tales so uniques and valuable but they can bring the whole magic world to a young reader and learner. They can open the old wisdom and knowledge of humankind which we often forget about".

Interesting plots in a fairy tale will encourage children to learn universal values and explore those values in social life, including friendliness. In the other hand, folk stories and legends are always in top position that interest and populare for younger children up to about eleven (Tucker, 1972). Fictional stories have a deep reaching power to stimulate emotions, 
force engagement and endless reading. This is one of the ways to think, basic in organizing information and ideas, understanding a culture and stimulating human consciousness (Livo, 2003).

Besides the criteria as have been mentioned above, the sainsmatika fairytale books was built on rationale that friendliness can integrated to science and mathematics learning proccess with fairytale as a media. Integrating friendliness value into science and mathematics teaching material with the wisdom of fairytale as a package is the concept of sainsmatika fairytale books. This book had some content to enhance friendliness value for example: "Aku teman baik" (I'am kindly friend) which stimulate student to act responsive and sociable.

\section{MATERIAL \& METHOD}

In this study, the student groups' examined to respond some open-ended problem which presented during 3 (three) week instructions. Students responses and activity were scored on 5 -point scale. The final result for this study is investigating the use of Sainsmatika Fairytale Book as a tool to enhance student friendliness.

\section{Participants}

The population involved in this research consists of 80 fourth-grade students in Daerah
Istimewa Yogyakarta Province in Indonesia. These research subjects are 37 male students and 43 female students who live in a homogenous area, which is a highland area not far from the city center. The respondents were selected through a purposive sampling technique, where only fourth-grade students of elementary schools which are appointed to undertake pilot projects of the national curriculum of Indonesia were involved.

\section{Problem Selection}

Five indicator of friendliness character were selected and adapted for the stories' activity content (Table 1). The indicator such as sociable, glad to share, respect to other, reciprocity, and open-mindedare adapted to the fairy stories.

The activity content problem was develop based on area and perimeter and also sound energy substance. Students are requested to solve the problem with their classmates. They will be faces difficulty if don't accustomed to independently share their idea.

\section{Design and Procedure}

During the 3 week study, experimental group engaged in instruction which using SFB (Sainsmatika Fairytale Book) as teaching tool. Student were randomly split into groups and learn to intermingle with everyone in classroom.

Table 1. Sainsmatika Activity Content X Fairy Stories.

\begin{tabular}{|c|c|c|}
\hline Fairy Stories Content & Objectives & Friendliness Character \\
\hline $\begin{array}{l}\text { Atta found some random } \\
\text { picture and requested to find } \\
\text { the connection to be among } \\
\text { mentioned picture. }\end{array}$ & $\begin{array}{l}\text { Student randomly choose unusual mate to seat } \\
\text { on the next her/him and help Atta to found the } \\
\text { connection between some random picture }\end{array}$ & $\begin{array}{l}\text { Try to working with random } \\
\text { people (sociable) }\end{array}$ \\
\hline $\begin{array}{l}\text { The magical door in the gave } \\
\text { only want to open if Atta could } \\
\text { mention as much as thing which } \\
\text { have area and perimeter }\end{array}$ & $\begin{array}{l}\text { Mention as much as thing which have area and } \\
\text { perimeter or usually looked for area and perimeter } \\
\text { with your classmates. }\end{array}$ & $\begin{array}{l}\text { Glad to share knowledge to } \\
\text { another student }\end{array}$ \\
\hline $\begin{array}{l}\text { Guiliram (a dreadful monster) } \\
\text { give a challenge for Atta to } \\
\text { arrange his castle }\end{array}$ & $\begin{array}{l}\text { Create a home plans in plot paper based on area } \\
\text { and perimeter measurement and show it to your } \\
\text { classmates. }\end{array}$ & Learning to respect other work \\
\hline $\begin{array}{l}\text { Peri Hutan had a challenge to } \\
\text { measuring fort (multiple shape) }\end{array}$ & $\begin{array}{l}\text { You need to see and properly score your classmates' } \\
\text { work }\end{array}$ & $\begin{array}{l}\text { Reciprocity to find the possible } \\
\text { problem solving with another } \\
\text { student }\end{array}$ \\
\hline $\begin{array}{l}\text { Every night, Atta seeing at star, } \\
\text { he imagine could explore the } \\
\text { space and investigate the sound } \\
\text { of space. }\end{array}$ & $\begin{array}{l}\text { Disccuss with your friend to find the possible way to } \\
\text { measure area and perimeter of multiple shape. } \\
\text { Share and response as much as logically question } \\
\text { about sound energy in space with your classmates. }\end{array}$ & $\begin{array}{l}\text { Share and accept another student } \\
\text { responses }\end{array}$ \\
\hline
\end{tabular}


Student reading the opening page of SFB together. In the middle of the reading activity, teacher give opportunity to student reading aloud the SFB in front of classroom. After a pure atmosphere, then student offered opportunity to answer the challenge they found in SFB.

The control group engagged with the conventional method. Teacher explain and demonstrate the principal theory of sound energy and area perimeter. In elaboration, student discuss to solve a problem which given by teacher. At the end of instruction, student take a daily test to assess their comprehention.

\section{Evaluation Instrument}

Students' performance level assessing based on their behavior during the instruction. The data were collected through observation and questionnaires. The observation using checklist with 3 rate scoring (never $=0$ point, rare $=1$ point, often $=2$ point, always $=3$ point). Some observers were present during the process of learning to watch students' behaviors and assess their characters.

\section{Data Analyze}

The collected quantitative data were then analyzed using a descriptive and one way ANOVA statistics method with the error rate at $5 \%$. It is to determine if the use of sainsmatika fairytale books significantly affects students' character of friendliness.

\section{RESULTS\& DISCUSSION Results}

Based on the collected data through observation, it is found that the character of friendliness of students who learned through sainsmatika fairytale books shows significant enhancement if compared to students who did not learn through sainsmatika fairytale books. In diagram 1 , the descriptive analysis of observation results of students' behaviors during the process of learning is presented. This data show that friendliness enhancement of experimental class is higher than control class.

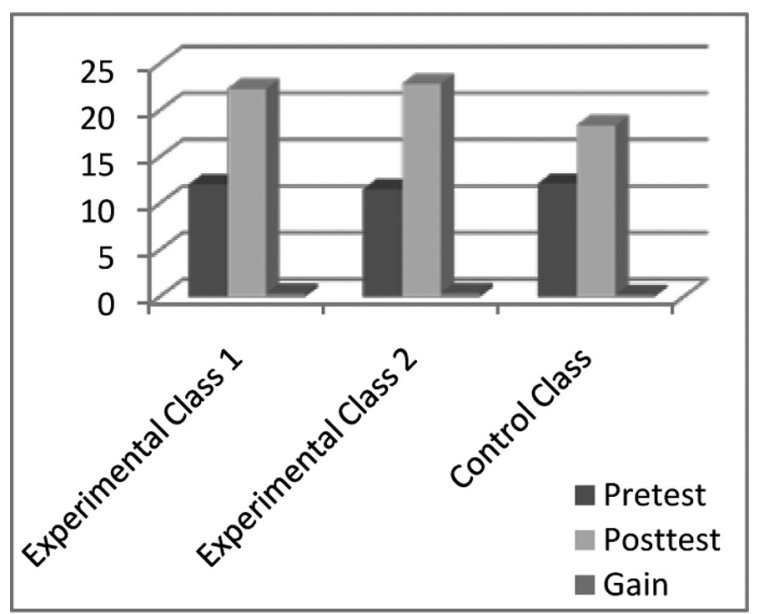

Diagram 1. The Comparison of

Enhancement of Students' Character of Friendliness Based on The Observation Results

In diagram 1, it can be seen that there is significant difference shown by the experimental classes and the control class regarding the enhancementofstudents'characteroffriendliness. Based on the data collected from the observation during the process of learning, it is found that the gain scores which represent the enhancement of students' character of friendliness shown by the results of treatment in the experimental classes are close each other, which are 0,3 and 0,4 . However, the gain score of the control group is only 0,2 . This finding specifically shows that the gain scores of the experimental classes are higher than the gain score of the control group. Based on the results of observation, it can be said that the use of fairytale books enhance the students' character of friendliness at the medium level of effectiveness.

Table 1. The One-Way Analysis of Variance Based on The Results of Observation

\begin{tabular}{lcccc}
\hline & df & MS & F & Sig. \\
\hline Between Groups & 2 & .232 & 7.725 & .001 \\
Within Groups & 77 & .030 & & \\
\hline Total & 79 & & & \\
\hline
\end{tabular}

Ho: $\mu 1=\mu 2=\mu 3=0$

H1: there must be $\mu$ with different values at a minimum of one pair

In table 1, it can be seen the gained significant difference is at the level of 
$0.001<0.05$. This indicates that there is significant mean difference at the minimum of one pair of population, so next the post hoc test is conducted to find out which pair of population has significant mean difference.

The post hoc test shown that the mean difference between experimental class 1 and control class is significant at the 0.05 level (mean difference $=.1346^{*}$ ). It is also happened between experimental class 2 and control class (mean difference $=.1794^{*}$ ). From these results, it can thus be concluded that there is significant difference regarding character of friendliness between experimental classes ( $1 \& 2)$ and control class.

Based on table 3 , the subset for alpha 1 is only one score, and the subset for alpha 2 is two score. The result show that the mean score of experimental class 1 and experimental class 2 is different. And, the mean score of control class is significantly different with both mean score of experimental class 1 and experimental class 2 .

\section{Discussion \\ Through Story, Student do Self- Reflection About Friendliness Value}

A fairy tale as part of children's literature does not only bring entertainment, but it also allows moral values which are believed by the society as the truth to be passed down from generation to generation. Even by people in the past, a fairy tale is considered to be the only way to teach readers especially children about important values in life. Indeed, a fairy tale exists through its mission to deliver moral teachings. It sets examples which provide guidance on how one should behave and live his life, and the messages it contains are usually implied or expressed through pictures or persuasive plots.

The friendliness value in story of Sainsmatika Fairytale Book (SFB) gives students the chances to practice self-reflection, encouraging them to feel as if they are parts of the story so they are emotionally engaged to take good examples from their experiences through the fairy tale. As a literarywork, a fairy tale is a medium which can effectively teach the children

Table 2. The Post Hoc Test Based on The Observation

\begin{tabular}{lllcrr} 
& (I) Method & (J) Method & Mean Difference (I-J) & Std. Error & Sig. \\
& \multirow{2}{*}{ Experimental class 1 } & Experimental class 2 &,- 0448 &, 0472 & .611 \\
& & Control class &, $1346^{*}$ &, 0481 & .018 \\
Tukey HSD & \multirow{2}{*}{ Experimental class 2 } & Experimental class 1 &, 0448 &, 0472 & .611 \\
& & Control class &, $1794^{*}$ &, 0472 & .001 \\
& \multirow{2}{*}{ Control class } & kelas_eksperimen1 &,$- 1346^{*}$ &, 0481 & .018 \\
& & Experimental class 2 &,$- 1794^{*}$ &, 0472 & .001 \\
& \multirow{3}{*}{ Experimental class 1 } & Experimental class 2 &,- 0448 &, 0472 & 1.000 \\
& & Control class &, $1346^{*}$ &, 0481 & .019 \\
Bonferroni & \multirow{2}{*}{ Experimental class 2 } & Experimental class 1 &, 0448 &, 0472 & 1.000 \\
& & Control class &, $1794^{*}$ &, 0472 & .001 \\
& \multirow{2}{*}{ Control class } & Experimental class 1 &,$- 1346^{*}$ &, 0481 & .019 \\
& & Experimental class 2 &,$- 1794^{*}$ &, 0472 & .001
\end{tabular}

Table 3. The Homogeneous Subsets Test Based on The Observation

\begin{tabular}{|c|c|c|c|c|}
\hline & \multirow{2}{*}{ Method } & \multirow{2}{*}{$\mathrm{N}$} & \multicolumn{2}{|c|}{ Subset for alpha $=0.05$} \\
\hline & & & 1 & 2 \\
\hline \multirow{4}{*}{ Tukey HSD ${ }^{\mathrm{a}, \mathrm{b}}$} & Control class & 26 & ,238 & \\
\hline & Experimental class 1 & 26 & & ,373 \\
\hline & Experimental class 2 & 28 & & ,418 \\
\hline & Sig. & & 1.000 & .615 \\
\hline
\end{tabular}


about moral values, appropriate attitude, social norms and ethics.

The similiar thing is also expressed by Danandjaja (2007, p.83), that a fairy tale is created primarily for entertainment, although it can also be imbued with moral teachings, life lessons and even satirical messages. In addition, Carvalho-Neto (Danandjaja, 2007, p.4) says that the usefulness of a fairy tale can be manifested in teaching materials, and it can also be effective as a source of solace, a projection of pent-up desire, and social criticism. At the age of 7-11 years old, children are able to contruct and identify specific conceptions about character after they have been through many experiences in life. For example, they will develop various perspectives when they read a fairy tale, hoping that the good figures in the story can win in whatever adventures they are involved in and that the story can have a happy ending. In this range of age, children love reading fictional stories which tell about adventures, so they can use their imagination to feel as if they experience the adventures (Tucker Tucker, 1989). Therefore, a fairy tale can be used as a medium to teach children specifically in the scope of character education. During the concrete operational stage, children will develop the ability to perceive their surroundings with different points of view. In this stage their logical thinking will improve, and therefore they need to read books which can connect them to different points of view, provide facts and deeper information, and challenge them to solve problems, mysteries or riddles (Mitchell, 2003: 12).

According to Kilic (2015, p.388), "fairy tale is one of the most important genres in literature which reflects childish sensitivity, feeds child's soul, enriches his/her imagination and prepare him/her for the future". Specifically when children grow sensitivity, they will be curious about problems which happen in their social environment. With the character value of friendliness manifested in a fairy tale, children can read it and develop their sensitivity when socializing with other people. It can stimulate them to respect others and help them maintain positive thinking. Furthermore, they canplace themselves as agents who also take the responsibilities of solving the problems in their environment, and this is a good example which they take and follow from the fairy tale.
The results of this reseach reveal that the use of sainsmatika fairytale books is effective to enhance students' character of friendliness. This is in accordance with the opinion of Huck, et al (1987, p.6-14), that a fairy tale as children's literature gives advantages which are divided into two kinds: personal values and education values. Regarding personal values, a fairy tale gives positive influences on children's development, such as improving their emotional development, intellectual development, and imagination development, as well as improving their social, ethical and religious senses.Then, regarding education values, a fairy tale can motivate children to explore their environment and discover the truth about phenomena happening around them, which can be very useful to cultivate their linguistic skills, sense of art, multicultural insights and habit of reading.

\section{Improve Student Friendliness Through Direct Activity}

Every child is a part of society. In the next decade, children will grow up and become changemakers of the world. As a part of society, a child as an individual needs basic social skills such as showing genuine respect, caring for others, and communicating well. However, there is no way that a child can possess these social skills in an instant. To have well-developed social skills, a child is indeed required to get actively involved in the real situations of social interaction. Only through personal experiences can a child learn how to interact with other people and find the value his social life.

From the perspectives of cognitive social development theories, social interaction is very important for children because it will help develop their conceptions of social and moral rules (Smetana, 2006; Turiel, 1998). With social interaction, a child can deepen his understanding of moral principles manifested such as in reciprocity and cooperation, fairness and human welfare (Horn et.al, 2014). Going along with the above-mentioned notions, Piaget (1932), Kohlberg (1969) and domain theories affirm that the development in the moral domain is encouraged through direct interaction and children's real experiences in social relations, as well as the consequences of every action when they build relationships with others (Nucci, 2014, p.396). Moral development is fostered by 
the opportunity for children to interact with other individuals in their social environment. When they socialize with their contemporaries, moral understanding which include positive attitude toward others, openness and courage to express themselves will gradually grow and improve over time.

The direct activity content in Sainsmatika Fairytale Book (SFB) require student adapted to outgoing atmosphere. Changing mate who seat next the student, discuss, share the idea and responses to another student statement is effective strategy to make student more sociable. "School is a social context" (Horn et.al, 2014, p. 393 ). It is a place where there is complex social interaction between teachers and students, and students with other students. Through social interaction in school, students are provided with direct experience of socialization. However, not all students are able to explore their social environment on their own initiative. The direct activity content in SFB being stimully student desire to socialize, and being media which can inspire them and provide them with insights into the culture of positive social interaction.

\section{CONCLUSION}

Sainsmatika Fairytale Books (SFB) is a tool to improve students' friendliness character. The differences among SFB and the general fairytale is SFB containing science and mathematics' content so SFB can used as a learning tool in instructional situation. The friendliness value, which developed to the fairy stories gradually changes student perspective about friendship and direct the student to reflect they behavior to another people. The direct activity content in SFB, had much role to improve student friendliness. During the instruction, student is encouraged to speak, listen and share their perspective, idea or responses to all classmates. One most difference atmosphere is they learn to apreciate and accept the another student without except for. The stimuli, like fairystories is a precise tool to enhance student friendliness. Teacher can also adapted this approach to improve student friendliness character using another popular fairystories, like 'Tinkerbell' or 'Peterpan' with a little alteration. So it can used as a learning tool in classroom situation and accepted by all students.

\section{ACKNOWLEDGEMENTS}

The authors would like to thank of the Ministry of Research, Technology, and Higher Education of Indonesia for their funding support of this research.

\section{REFERENCES}

Australian Primary Schools Mental Health Initiative. 2013. Helping children learn positive friendship skills. Accessed from www.kidsmatter.edu.au.

Bennett, J., Espie, C., Duncan, B., Minnis, H. 2009. A qualitative exploration of children's understanding of indiscriminate friendliness. Clinical Child Psychology and Psychiatry, 14(4), 595-618. DOI: $10.1177 / 1359104509339137$.

Borba, M. 2015. Friendship matters: Helping kids make friends. Online article. Accessed from http://micceleborba.com/teachingkids-friendship-making-skills/.

Cuddon, J. A. 1998. A dictionary of literacy terms and literacy theory (4th ed.). Revised by Preston C.E. Oxford: Blackwell Publishers Ltd.

Davidson, M., Lickona, T., \& Khmelkov, V. 2006. Building smart \& good schools. Unpublished manuscript. Center for the 4th and 5th Rs and the Institute for Excellence and Ethicks.

Dananjaja, James. 2007. Folklore indonesia ilmu gosip, Dongeng dan Lain-lain. Jakarta: Pustaka Utama Grafiti.

Fathurrohman, P., Suryana, A., \& Fatriani, F. 2013. Pengembangan pendidikan karakter. Bandung: Refika Aditama.

Grose, M. 2008.12 friendship skills every child needs. Online article. Accessed in 22 November 2016. Downloded in parentingideas.com.au.

Hall, C., Domhoff, C. 1967 . Friendliness in dreams. The Journal of Social Psychology, 62(2), 309-314, DOI: 10.1080/00224545.1964.9919528. 
Horn, S. S., Daddis, C., \& Killen, M. 2014. Hubungan sebaya dan kelompok: Dampaknya bagi pendidikan moral.

Huck, C., et.al. 1987. Children literature in elementary scholl. Chicago: Rand McNally College Publishing Company.

Indonesia National Ministry of Education. 2011. Panduan pelaksanaan pendidikan karakter. Badan Penelitian dan Pengembangan Pusat Kurikulum dan Perbukuan. Jakarta.

Joseph, G.E., Strain, P., Yates, T. 2010. Social emotional teaching strategies. Presenter scripts. The Center on The Social and Emotional Foundations for Early Learning.

Gabitov, A.I. \& Ilyasova, L.G. 2016. Use of automated instruments of text analysis to provide proper difficulty level of English language educational materials. Problems of Modern Pedagogical Education: Pedagogy and Psychology, 53(3), 101108.

Kilic, Y. 2015. Survey on effects of fairy tales on Turkish language training from secondary school students' perspective. Educational Reasearch and Reviews, 10(4): 388.

Kohlberg, L. 1969. Stage and sequence: the cognitive-developmental approach to socialization. In D. A. Goslin (Ed.).Handbook of socialization theory and research.Chicago: Rand McNally.

Lepin, M. 2012. Fairy tales in teaching english language skills and values in school stage II. Unpublished bachelor thesis, University of Tartu, Tartu.

Livo, N.J. 2003. Bringing out their best values education and character development through traditional tales. Westport: A Division of Greenwood Publishing Group, Inc.
McElmeel, S. 2002. Character education: A book guide for teachers, librarians, and parents. Greenwood Village: Libraries Unlimited.

Mitchell, D. 2003. Children literature: An invitation to the world. Florida: Pearson, Allyn \& Bacon.

Nucci, L.P \& Marvaez, D. 2014. Handbook pendidikan moral dan karakter (Baehaqie, I. \& Widowatie, D.S.). Bandung: Penerbit Nusa Media. (Original work published 2008).

Piaget, J. 1932/1965. The moral judgement of the child. New York : Free Press.

Saxby, M. 1991. Give Them Wings: The Experience of Children's Literature. Melbourne: Macmillan Company of Australia.

Smetana, J.G. 2006. Social cognitive-domain theory: Consistencies and variations in children's moral and social judgements. In M. Killen \& J. Smetana (Eds.). Handbook of Moral Development. Mahwah, NJ: Erlbaum.

Solnyshkina, M.I., et.al. 2017. English textbooks for Russian students: Problem and specific features. Journal of Social Studies Education Research, 8(3), 215-226.

Sulhan, N. 2011. Panduan praktis pengembangan karakter dan budaya bangsa sinergi sekolah dengan rumah. Surabaya: Jaring Pena.

Suyadi. 2013. Strategi pembelajaran pendidikan karakter. Bandung: PT Remaja Resdakarya.

Tucker, N. 1972. How children respont to fiction. Child Literature in Education, 3(48), 4856. DOI: 10.1007/BF01139460.

Turiel, E. 1998. The development of morality. In W. Damon (Series Ed.) \& N. Eisenberg (Vol. Ed.), Handbook of child psychology: Vol 3, social, emotional, and personality development (6th ed.). New Yor: Wiley. 